\title{
Intussusception of the Appendix Induced by Sessile Serrated Adenoma: A Case Report
}

\section{Sesil Serrated Adenomun Uyardığı Apendiks İntüsüsepsiyonu}

\author{
Ümran YILDIRIM', İsmet ÖZAYDIN² ${ }^{2}$, Havva ERDEM' ${ }^{1}$, Ali Kemal UZUNLAR'
}

Departments of ${ }^{1}$ Pathology and ${ }^{2}$ General Surgery, Düzce University, Faculty of Medicine, DÜZCE, TURKEY

\section{ABSTRACT}

Intussusception of the appendix vermiformis is a rare condition. It occurs mainly in infants and children. Here, we report an intussusception case that occurred in a 65-year-old male presenting with repeated periumbilical pain, nausea, vomiting and febrile sensation. The appendix was seen to be intussuscepted at laparoscopy. The invaginated segment was reducted and simple appendicectomy was carried out. Histopathologic examination revealed a sessile serrated adenoma at the wall of the appendix, suggesting it as the cause of the intussusception.

Key Words: Appendix, Intussusception, Serrated adenoma

\section{ÖZ}

Apendix intüsüsepsiyonu nadir bir durumdur. Literatürde yayınlanan olguların çoğunu infant ve çocuklar oluşturmaktadır. Biz burada 65 yaşında tekrarlayan karın ağrısı, mide bulantısı ve kusma ile merkezimize kabul edilen erkek hastayı sunduk. Laporoskopide appendix dokusu invajine idi fakat redükte edilebilme ihtimali vardi. Bu nedenle basit apendektomi gerçekleştirildi. Histopatolojik inceleme apendix lümeninde sesil serrated adenomu göstermiştir ve bu da intüsüsepsiyonun kaynağının bu lezyon olduğunu düşündürmüştür.

Anahtar Sözcükler: Apendiks, İntüsüsepsiyon, Serrated adenoma

\section{INTRODUCTION}

Intussusception primarily occurs in children, with only about $5 \%$ of cases occurring in adults (1). Intussusception of the appendix vermiformis in adults is a rare condition caused by anatomical and pathological factors such as tumors and is rarely diagnosed before surgery. Although most appendiceal tumors are benign, tubular adenoma is an unusual lesion (2). Here, we report a case with appendiceal intussusception induced by sessile serrated adenoma (SSA) and discuss the clinical features, classification, preoperative diagnosis and therapy of this condition together with a review of the literature.

\section{CASE REPORT}

A 65-year-old male was admitted with repeated periumbilical pain, nausea, vomiting and febrile sensation. His initial vital signs were blood pressure $102 / 68 \mathrm{mmHg}$, pulse $102 / \mathrm{min}$, respiration $18 / \mathrm{min}$, and temperature $37.5{ }^{\circ} \mathrm{C}$. Abdominal examination revealed a right lower quadrant tenderness with voluntary guarding and mild rebound tenderness. Pelvic examination and urinalysis were normal with no evidence of haematuria or other findings (such as infection). The WBC was $15.3 \times 103 / \mu \mathrm{L}$ with $78 \%$

(Turk Patoloji Derg 2012, 28:290-292)

Received : 05.09.2010 Accepted : 21.02.2011 neutrophils and the C-reactive protein level was $87.2 \mathrm{mg} / \mathrm{dl}$. This presentation indicated acute appendicitis. Plain films of the abdomen disclosed multiple intestinal air-fluid levels (Figure 1). After appropriate fluid replacement, the patient underwent emergency surgery. The appendix was seen to be intussuscepted at surgery. The invaginated segment was reducted and simple appendicectomy, rather than a right hemicolectomy was carried out in the absence of any other findings. Histopathologic examination revealed an SSA at the wall of the appendix (Figure 2).

\section{DISCUSSION}

Intussusception was described firstly by Barbette of Amsterdam in 1674 and further presented in a detailed report in 1789 by John Hunter as "introssusception". Intussusception represents a rare form of bowel obstruction in the adult (1). Several pathological conditions have been reported as the leading point in intussusception, and these include polyps, hamartomas, lipomas, leiomyomas, neurofibromas, adenomas, inflammatory polyps, tuberculosis, Meckel diverticulum, adhesions, and heterotopic pancreas in children (1). Adult intussusception represents $5 \%$ of all cases of intussusception and accounts

Correspondence: Ümran YILDIRIM

Department of Pathology, Düzce University, Faculty of Medicine, DÜZCE, TURKEY

E-mail: umranyildirim@duzce.edu.tr Phone: +90 5336305669 


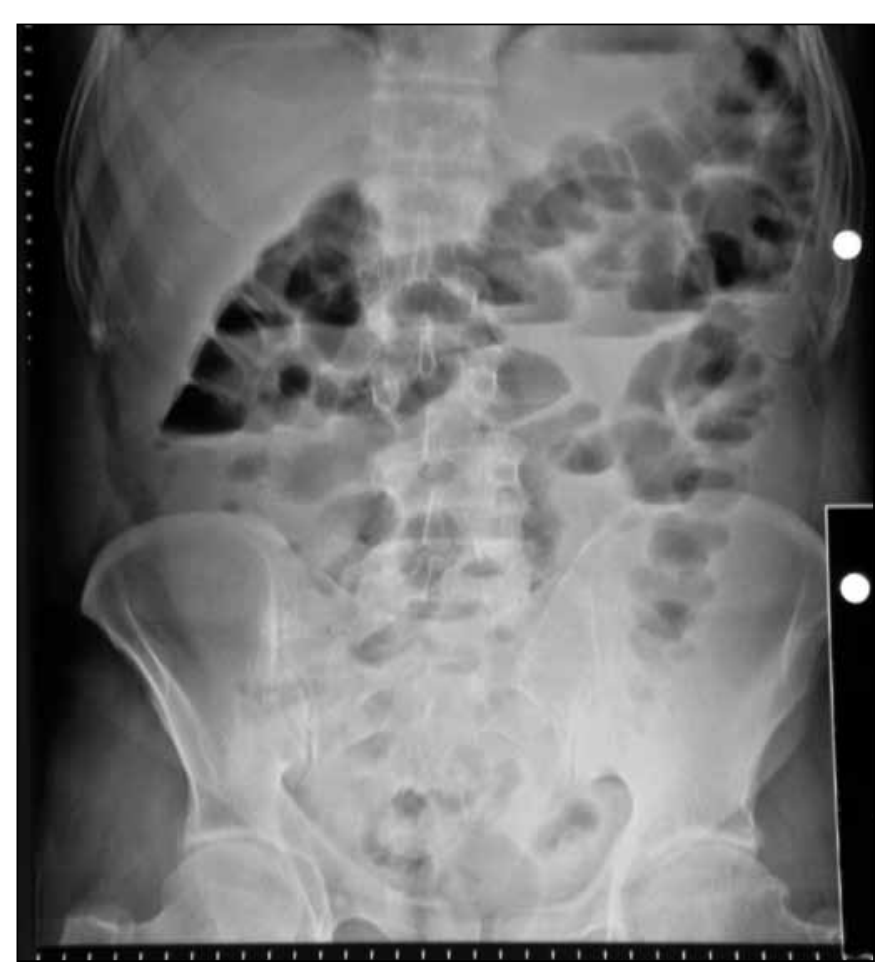

Figure 1: Plain film of abdomen disclosing multiple intestinal airfluid levels.

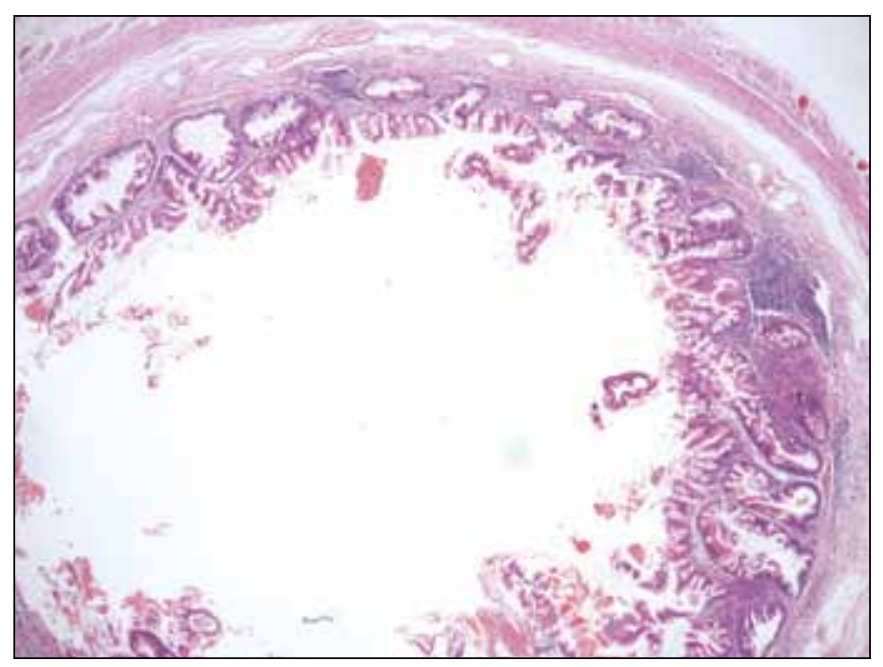

Figure 2: Microphotograph shows sessile serrated adenoma involving the entire appendiceal circumference (H\&E, x4).

for only $1 \%-5 \%$ of intestinal obstructions in adults (3). In children, it is usually primary and benign, and pneumatic or hydrostatic reduction of the intussusception is sufficient to treat the condition in $80 \%$ of the patients. In contrast, almost $90 \%$ of the cases of intussusception in adults are secondary to a pathologic condition that serves as a lead point, such as carcinomas, polyps, Meckel's diverticulum, colonic diverticulum, strictures or benign neoplasms, which are usually discovered intraoperatively (3).
Intussusception of the appendix vermiformis is an uncommon and an incidence rate of $0.01 \%$ has been reported in the literature $(4,5)$. Most of the cases in the literature are infants and children (6). Our case was an adult male patient.

Some anatomical factors such as a fetal-type cecum with a funnel-shaped, mobile appendix may also cause intussusception of the appendix vermiformis $(7,8)$. The clinical presentation in adult intussusception is often chronic, and most patients present with nonspecific symptoms that are suggestive of intestinal obstruction. Abdominal pain is the most common symptom followed by vomiting and nausea $(3,9,10)$. Our case was admitted as acute appendicitis and intussusception of the appendix was recognized during surgery.

Several imaging techniques such as plain abdominal X-rays, contrast studies, barium enema examination, colonoscopy, USG, and in recent years CT and MRI may help to precisely identify the causative lesion preoperatively (11). Barium enema examination and colonoscopy are contraindicated if there is the possibility of bowel perforation (11).

There are a few cases appendiceal intussusception in the literature. In one of them, the intussusception was caused by appendiceal malignant polyp in a patient with PeutzJeghers syndrome (12) and other cases were caused by endometriosis (4) and appendicitis (13). Our case is the first appendiceal intussusception induced by SSA.

SSA is a recently described entity. It is more commonly located in the right side of the colon and also can occur in the appendix (14-16). The incidence of this lesion in the appendix is unknown (17). SSA cases closely resemble hyperplastic polyps morphologically but exhibit subtle distinguishing architectural and cytologic features, such as dilatation and serration of the basis of crypt, irregular branching and asymmetric crypt (17). SSA can mimic a hyperplastic polyp (HP) in the appendix but differs from HP by the lack of dysplastic changes in the crypt epithelium (17). Bellizzi et al. demonstrated that SSA of the appendix was morphologically and immunophenotypically analogous to those seen in the colorectum (18). However, they exhibited different rates of BRAF mutation and the lack of demonstrable resultant microsatellite instability (19).

In conclusion, intussusception of the vermiform appendix is rare. Clinical signs, symptoms and radiological findings vary among patients. Treatment of appendiceal intussusception is mainly surgical. SSA is one of the probable diagnoses in adults that should be considered in obstructive lesions of the appendix causing intussusception. 


\section{REFERENCES}

1. Marinis A, YiallourouA, SamanidesL,DafniosN,Anastasopoulos G, Vassiliou I, Theodosopoulos T: Intussusception of the bowel in adults: A review. World J Gastroenterol 2009, 28: 407-411

2. Chen YC, Chiang JM: Appendiceal intussusception with adenocarcinoma mimicking a cecal polyp. Gastrointest Endosc 2000, 52:130-131

3. Azar T, Berger DL: Adult intussusception. Ann Surg 1997, 226: 134-138

4. Ijaz S, Lidder S, Mohamid W, Carter M, Thompson H: Intussusception of the appendix secondary to endometriosis: a case report. J Med Case Rep 2008; 2:12

5. Collins DC: 71,000 human appendix specimens. A final report, summarizing forty years' study. Am J Proctol 1963, 14:265-281

6. Forshall I: Intussusception of the vermiform appendix with a report of seven cases in children. Br J Surg 1953, 40:305-312

7. Fink VH, Santos AL, Goldberg SL: Intussusception of the appendix: case reports and review of the literature. Am J Gastroenterol 1964, 42: 431-441

8. Hill BJ, Schmidt KD, Economou SG: The "insideout" appendix. A review of the literature and report of two cases. Radiology 1970, 95:613-617

9. Begos DG, Sandor A, Modlin IM: The diagnosis and management of adult intussusception. Am J Surg 1997, 173: 88-94

10. Levine MS, Trenkner SW, Herlinger H, Mishkin JD, Reynolds JC: Coiled-spring sign of appendiceal intussusception. Radiology $1985,155: 41-44$
11. Yakan S, Caliskan C, Makay O, Denecli AG, Korkut MA: Intussusception in adults: Clinical characteristics, diagnosis and operative strategies. World J Gastroenterol 2009, 28:1985-1989

12. Miyahara M, Saito T, Etoh K, Shimoda K, Kitano S, Kobayashi $M$, Yokoyama S: Appendiceal intussusception due to an appendiceal malignant polyp an association in a patient with Peutz-Jeghers syndrome: report of a case. Surg Today 1995, 25:834-837

13. Ozuner G, Davidson P, Church J: Intussusception of the vermiform appendix: preoperative colonoscopic diagnosis of two cases and review of the literature. Int J Colorectal Dis 2000, 15:185-187

14. Baker K, Zhang Y, Jin C, Jass JR: Proximal versus distal hyperplastic polyps of the colorectum: different lesions or a biological spectrum? J Clin Pathol 2004, 57:1089-1093

15. Higuchi T, Jass JR: My approach to serrated polyps of the colorectum. J Clin Pathol 2004, 57:682-686

16. Rubio CA: Serrated adenoma of the appendix. J Clin Pathol 2004, 57:946-949

17. Carr NJ, Emory TS, Sobin LH: Epithelial Neoplasms of the Appendix: In Odze RD, Goldblum JR (Eds): Surgical Pathology of the GI Tract, Liver, Biliary Tract and Pancreas. Philadelphia, Saunders, 2009, 639-653

18. Bellizzi AM, Rock J, Marsh WL, Frankel WL: Serrated lesions of the appendix: a morphologic and immunohistochemical appraisal. Am J Clin Pathol 2010, 133:623-32

19. Rubio CA: Serrated adenomas of the appendix. J Clin Pathol 2004, 57:946-949 